\title{
Employment Structure Transformations in Large Polish Cities
}

\author{
Katarzyna PRZYBYŁA \\ Wrocław University of Environmental and Life Sciences, Wrocław, Poland \\ katarzyna.przybyla@upwr.edu.pl
}

\begin{abstract}
The article identifies and provides the assessment of changes occurring in the labour market structure of Polish voivodship cities. Bray-Curtis measure was used to analyse these transformations. The time span of the study covered the years 2005-2015.

The conducted analysis allowed identifying the groups of cities characterised by a similar range of changes in the labour market structure. It was also attempted to analyse the relationship between Bray-Curtis measure value and the level and rate of economic growth in the regions, the capitals of which are the analysed cities.
\end{abstract}

Keywords: Labour Market Structure, Polish Voivodship Cities.

\section{Introduction}

Labour market, representing the market for one of the production factors, was developed in the course of historical processes. In the national dimension (Poland) it is characterized by significant interregional differences, manifested by a different unemployment rate recorded in various areas and also by the diversified employment structure in particular economy sectors. Identifying the labour market situation remains the necessary component (stage) of the carried out economic policy, including the regional one. Moreover, since the market functions as a regulator of economic processes, its sustainability is important from the perspective of broader development processes taking place in economy. In order to assess development processes it seems reasonable to use the indicato-based assessment, which can effectively support local management processes [3].

After the administrative reform, which came into force on 1st January 1999 [cf. 8], sixteen new voivodships were established in Poland, and simultaneously eighteen cities started playing the function of their capitals - voivodship capital cities. Fourteen of them i.e. Białystok, Gdańsk, Katowice, Kielce, Kraków, Lublin, Łódź, Olsztyn, Opole, Poznań, Rzeszów, Szczecin, Warszawa and Wrocław are also the seats of the Voivode and local government authorities. These functions were separated in two voivodships. A different number of voivodships and voivodship capital cities prove the difficulty of delimiting regions in space [cf. 4]. In Kujawsko-Pomorskie voivodship the city of Bydgoszcz is the seat of the Voivode, whereas the city of 
Torun is the seat of the voivodship Parliament and the Marshal's Office. A similar situation occurs in Lubuskie voivodship: Gorzów Wielkopolski is the Voivode's seat, whereas Zielona Góra the seat of local government authorities [7, 11]. In spite of the fact that all the analysed cities, in accordance with the typological classification adopted in Poland [cf. 1] can be included in the group of at least large cities (more than 100000 residents), there are significant differences in their size (Tab. 1) and internal socio-economic structure [15].

Table 1. Population number in Polish voivodship cities [5].

\begin{tabular}{lr}
\hline \multicolumn{1}{c}{ City } & Population number in $\mathbf{2 0 1 5}$ \\
\hline Opole & 118931 \\
Gorzów Wielkopolski & 123762 \\
Zielona Góra & 138711 \\
Olsztyn & 173444 \\
Rzeszów & 185896 \\
Kielce & 198046 \\
Toruń & 202689 \\
Białystok & 295981 \\
Katowice & 299910 \\
Lublin & 340727 \\
Bydgoszcz & 355645 \\
Szczecin & 405657 \\
Gdańsk & 462249 \\
Poznań & 542348 \\
Wrocław & 635759 \\
Lódź & 700982 \\
Kraków & 761069 \\
Warszawa & 1744351 \\
\hline
\end{tabular}

The purpose of the article is to identify and evaluate changes occurring in the years 2005-2015 on the labour market structure of Polish voivodship cities. This period, following Poland's accession to the EU, was characterized by a dynamic economic growth of the country. In 2015 Polish GDP amounted to PLN 1798302 million, which was nominally worth 1.8 times more than the value recorded for 2005 . It seems that the ongoing development processes should be accompanied by adequate adaptation processes, taking place on the labour market. The study was carried out using BrayCurtis measure. An attempt was also made to determine the relationship between the 
level and rate of economic growth in the regions and the transformations occurring on this market.

\section{Research method}

For the purposes of the presented study it was adopted that the structure of employment is presented by employment percentage in 5 groups of NACE 2007 sections (Polish Statistical Classification of Economic Activities). Section A covers employment in agriculture, forestry, hunting and fishing and can be identified with the sector of agriculture. The group of B-F section includes industry and construction - the industrial sector. According to the Central Statistical Office's data collection method, the service sector was divided into three components. The group of G-J sections covers trade; repair of motor vehicles; transport and storage; accommodation and gastronomy; information and communication (Services I). Sections K-L represent financial and insurance activities; real estate services (Services II), and the group of M-U sections lists other services, including e.g. education, health care and social welfare, public administration and national defence; compulsory social security (Services III). It should be observed that in Polish context, the latter group is dominated by non-market services.

Bray-Curtis measure was applied to analyse transformations in employment structure in Polish voivodship cities.

If it is assumed that the numerical picture of employment structure in a given object, according to the groups of NACE 2007 sections, takes the form of a vector:

$$
\left[a_{1 k}^{t}, a_{2 k}^{t}, a_{3 k}^{t}, a_{4 k}^{t}, a_{5 k}^{t}\right]
$$

where:

$a_{1 k}^{t}$ - employment share in the first section grouping in $t$ moment (years), in $k$-th object $k=1, \ldots, K$,

$a_{2 k}^{t}$ - employment share in the second section grouping in $t$ moment (years), in $k$-th object $k=1, \ldots, K$,

$a_{3 k}^{t}$ - employment share in the third section grouping in $t$ moment (years), in $k$-th object $k=1, \ldots, K$,

$a_{4 k}^{t}$ - employment share in the fourth section grouping in $t$ moment (years), in $k$-th object $k=1, \ldots, K$,

$a_{5 k}^{t}$ - employment share in the fifth section grouping in $t$ moment (years), in $k$-th object $k=1, \ldots, K$,

which elements meet the dependence:

$$
\sum_{i=1}^{5} a_{i k}^{t}=1 \quad a_{i k}^{t} \geq 0,
$$

then Bray-Curtis measure evaluating changes in the value of vector (1) elements in $k$ th object (city) in two different moments $t=1,2$ takes the following form: 


$$
p_{k}=\frac{\sum_{i=1}^{5}\left|a_{i k}^{1}-a_{i k}^{2}\right|}{\sum_{i=1}^{5}\left(a_{i k}^{1}+a_{i k}^{2}\right)}
$$

then:

$$
p_{k} \in[0 ; 1]
$$

Almost zero values of Bray-Curtis measure can be estimated as slight changes in employment structure in the grouped NACE 2007 sections in a given object, in two comparable periods (years). Approximate to unity measure values mean significant changes in employment structure [6].

The groups of cities, characterized by a similar nature of transformations occurring in employment structure, were identified using hierarchical cluster analysis by applying the furthest neighbour method, in accordance with the size of Bray-Curtis measure.

Using Spearman's rank correlation coefficient, the relationship between BrayCurtis measure and GDP per capita in 2015 was analysed in these regions the capitals of which are the studied cities. The relationship between the value of the characterized measure and the level of economic growth in these regions in the time relationship 2005 - 2015 was also analysed. In addition, the relationship between the measure value and the city size, defined based on population number, was also analysed.

\section{$3 \quad$ Research results}

Tables 2 and 3 show employment shares in the groups of NACE 2007 sections in Polish voivodship cities in 2005-2015. It is noticeable that in both analysed years the service sector was definitely the dominating one in the studied cities [cf. 13, 12], with particular emphasis on Services III. It can be adopted that it results from the concentration of central type functions in regional capitals, i.e. the activities which also serve entities located in the city hinterland. In 2015 the employment share in the grouped M-U sections was the highest in all analysed cities (in 2005 Torun was the exception). In the relationship of the years 2005-2015 Services I gained importance against the industry sector. In 2005 in 8 out of 18 cities Services I were dominated by the industry sector, in 2015 such situation was true for only 4 cities (Bydgoszcz, Gorzów Wlkp., Łódź, Kielce). K-L grouping supplemented the economic landscape of cities, however, did not gain major significance in any of the regional capitals. Its rank was most prominent in Warszawa, where in 2015 it surpassed the importance of the industry sector. 
Table 2. Employment share in grouped NACE 2007 sections in Polish voivodship capitals in $2005[5]$.

\begin{tabular}{lccccc}
\hline $\begin{array}{c}\text { Territorial } \\
\text { unit/ } \\
\text { NACE 2007 } \\
\text { sections }\end{array}$ & $\begin{array}{c}\text { Agriculture, } \\
\text { forestry, } \\
\text { hunting and } \\
\text { fishing } \\
\text { (section A) }\end{array}$ & $\begin{array}{c}\text { Industry } \\
\text { and } \\
\text { construction } \\
\text { (sections }\end{array}$ & $\begin{array}{c}\text { Services I } \\
\text { (sections G-J) }\end{array}$ & $\begin{array}{c}\text { Services II } \\
\text { (sections } \\
\text { K-L) }\end{array}$ & $\begin{array}{c}\text { Services } \\
\text { III } \\
\text { (sections } \\
\text { M-U) }\end{array}$ \\
\hline POLAND & 21.5 & 29.4 & 17.1 & 3.9 & 28.2 \\
Wrocław & 0.7 & 25.0 & 26.4 & 7.1 & 40.8 \\
Bydgoszcz & 0.6 & 34.2 & 24.7 & 5.4 & 35.0 \\
Toruń & 0.8 & 36.8 & 23.5 & 5.0 & 33.9 \\
Lublin & 1.7 & 20.8 & 25.2 & 6.5 & 45.8 \\
Gorzów Wlkp. & 2.1 & 33.1 & 21.4 & 4.7 & 38.7 \\
Zielona Góra & 0.4 & 23.2 & 27.8 & 6.9 & 41.7 \\
Lódź & 1.0 & 29.8 & 23.1 & 6.0 & 40.0 \\
Kraków & 0.9 & 25.6 & 26.2 & 5.3 & 41.9 \\
Warszawa & 0.5 & 16.6 & 32.6 & 11.1 & 39.1 \\
Opole & 1.4 & 25.8 & 26.4 & 4.9 & 41.4 \\
Rzeszów & 0.4 & 30.9 & 24.9 & 5.6 & 38.2 \\
Białystok & 1.6 & 24.4 & 26.3 & 5.2 & 42.5 \\
Gdańsk & 0.9 & 26.4 & 26.0 & 7.4 & 39.3 \\
Katowice & 0.3 & 28.2 & 27.7 & 6.5 & 37.3 \\
Kielce & 1.0 & 30.3 & 24.5 & 4.7 & 39.5 \\
Olsztyn & 0.7 & 26.0 & 27.9 & 6.3 & 39.1 \\
Poznań & 0.9 & 27.2 & 28.9 & 5.8 & 37.3 \\
Szczecin & 1.0 & 25.8 & 28.4 & 6.2 & 38.7 \\
\hline & & & & & \\
\hline
\end{tabular}

Table 3. Employment share in grouped NACE 2007 sections in Polish voivodship capitals in 2015 [5].

\begin{tabular}{lccccc}
\hline $\begin{array}{c}\text { Territorial } \\
\text { unit/ } \\
\text { NACE 2007 } \\
\text { sections }\end{array}$ & $\begin{array}{c}\text { Agriculture } \\
\text { forestry, } \\
\text { hunting } \\
\text { and fishing } \\
\text { (section A) }\end{array}$ & $\begin{array}{c}\text { Industry } \\
\text { and } \\
\text { constructio } \\
\mathbf{n}\end{array}$ & $\begin{array}{c}\text { Services I } \\
\text { (sections G-J) } \\
\text { B-F) }\end{array}$ & $\begin{array}{c}\text { Services II } \\
\text { (sections } \\
\text { K-L) }\end{array}$ & $\begin{array}{c}\text { Services } \\
\text { III } \\
\text { (sections } \\
\text { M-U) }\end{array}$ \\
\hline POLAND & 21.0 & 26.9 & 19.0 & & \\
Wrocław & 0.7 & 18.7 & 26.9 & 8.8 & 29.2 \\
Bydgoszcz & 0.7 & 30.9 & 24.1 & 6.7 & 45.4 \\
Toruń & 0.8 & 27.3 & 27.4 & 5.9 & 37.7 \\
\hline
\end{tabular}




\begin{tabular}{llllll}
\hline Lublin & 4.0 & 17.9 & 25.1 & 7.2 & 45.8 \\
Gorzów Wkp. & 2.6 & 35.8 & 19.7 & 4.4 & 37.5 \\
Zielona Góra & 1.7 & 22.8 & 27.5 & 5.4 & 42.5 \\
Lódź & 0.9 & 25.1 & 24.6 & 6.7 & 42.8 \\
Kraków & 1.4 & 19.7 & 28.8 & 6.4 & 43.7 \\
Warszawa & 0.7 & 12.3 & 30.8 & 13.5 & 42.8 \\
Opole & 1.0 & 23.6 & 25.3 & 4.2 & 45.9 \\
Rzeszów & 3.9 & 24.5 & 25.0 & 4.4 & 42.1 \\
Białystok & 3.4 & 20.2 & 26.5 & 4.7 & 45.3 \\
Gdańsk & 0.8 & 21.1 & 28.7 & 7.9 & 41.5 \\
Katowice & 0.4 & 21.2 & 26.0 & 9.3 & 43.1 \\
Kielce & 1.8 & 26.7 & 24.5 & 3.7 & 43.3 \\
Olsztyn & 0.7 & 21.6 & 26.2 & 5.6 & 45.9 \\
Poznań & 0.8 & 20.7 & 27.8 & 6.3 & 44.4 \\
Szczecin & 1.3 & 19.9 & 29.9 & 5.5 & 43.4 \\
\hline
\end{tabular}

Based on the data in Tables 2 and 3, using the formula no. 3 the measurement of changes occurring in employment structure, in the analysed cities, was conducted. The values of calculated Bray-Curtis measure are presented in Tab. 4. Next using the method of the furthest neighbour four groups of cities were identified, in which the nature of structural changes was similar (Tab. 5).

Table 4. Bray-Curtis measures for employment structure in Polish regional capitals in the relationship 2005-2015

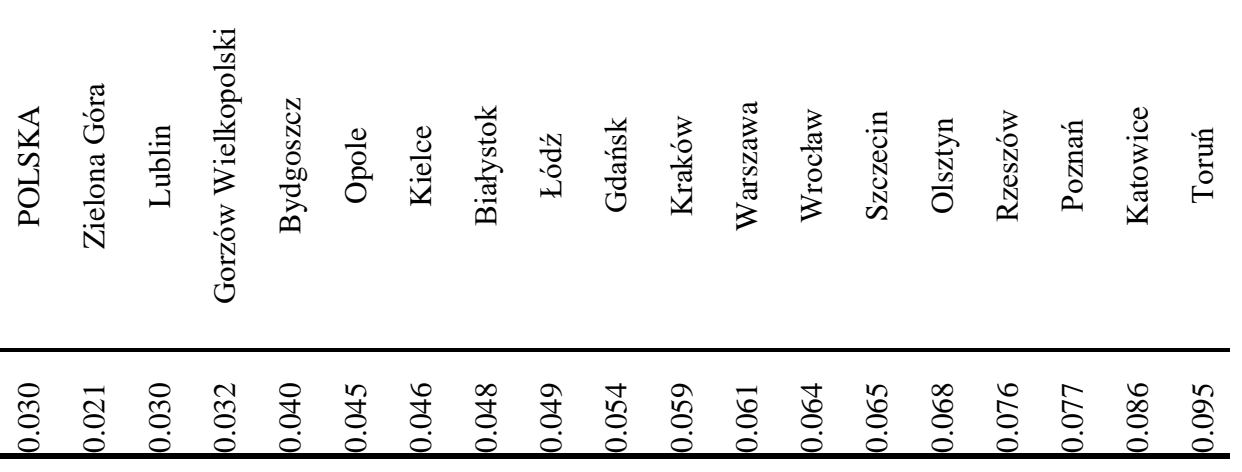


Table 4. The groups of cities identified using the furthest neighbour method in terms of BrayCurtis measure value for employment structure in the years 2005-2015

\begin{tabular}{|c|c|c|c|c|}
\hline Group & Cities & $\begin{array}{l}\text { Standard } \\
\text { deviation }\end{array}$ & $\begin{array}{l}\text { Intra-group } \\
\text { average }\end{array}$ & $\begin{array}{l}\text { Variation } \\
\text { coefficient }\end{array}$ \\
\hline 1 & $\begin{array}{c}\text { Zielona Góra } \\
\text { Lublin } \\
\text { Gorzów Wielkopolski }\end{array}$ & 0.0047 & 0.0276 & 0.170 \\
\hline 2 & $\begin{array}{l}\text { Bydgoszcz } \\
\text { Opole } \\
\text { Kielce } \\
\text { Białystok } \\
\text { Łódź } \\
\text { Gdańsk } \\
\text { Kraków } \\
\text { Warszawa }\end{array}$ & 0.0068 & 0.0503 & 0.135 \\
\hline 3 & $\begin{array}{l}\text { Wrocław } \\
\text { Szczecin } \\
\text { Olsztyn } \\
\text { Rzeszów } \\
\text { Poznań }\end{array}$ & 0.0054 & 0.0698 & 0.078 \\
\hline 4 & $\begin{array}{c}\text { Katowice } \\
\text { Toruń }\end{array}$ & 0.0044 & 0.0905 & 0.049 \\
\hline
\end{tabular}

It is worth noticing that the majority of voivodship capitals were characterised by higher value of Bray-Curtis measure and thus more dynamic transformations of labour market structure against the average country value (Tab. 4). In case of only 2 out of 18 cities (Zielona Góra and Lublin) this value was lower or equal the one characteristic for Poland. The following differentiation should be highlighted - the measure value for Zielona Góra was $(0,021)$, whereas for Torun it amounted to $(0,095)$.

The first group covers the cities characterised by the smallest range of changes in employment structure, and along with the relatively low numbers (Zielona Góra, Lublin, Gorzów Wielkopolski) they feature high variability reaching 17\%. Zielona Góra and Gorzów Wlkp. are the capitals of Lubuskie voivodship located in western Poland, by the German border. Lubelskie voivodship, with Lublin as its capital is situated in eastern Poland and borders with Byelorussia and Ukraine.

The second, most numerous group included 8 cities for which the average level of structural changes measure was higher than in the first group and amounted to 0,0503. Variation coefficient presented the level of $13,5 \%$. The group covers units dispersed all over the country.

The next group - measure value ranging from 0,064 to 0,077 , variability at the level of $7,8 \%$ - is made up of 5 cities (Wrocław, Szczecin, Olsztyn, Rzeszów, 
Poznań). The cities qualified for the third group were also dispersed all over the country and did not follow any clear territorial rule.

The separate, fourth group includes Katowice and Torun. In the analysed years these cities experienced the most extensive changes in the form of analysed structures, moreover, this group is also characterized by the lowest intra-group diversification variation at the level of $4,9 \%$.

Using Spearman's correlation coefficient, the strength of the relationship was also analysed between Bray-Curtis measure value and: GDP per capita in 2015 in the regions which capitals are the studied cities (A); the level of economic growth in these regions in the time relationship $2005-2015$ (B); measured by the city size based on its population number $(\mathrm{C})$. This coefficient takes numerical values in the closed range from -1 to +1 [cf. 14]. Due to the fact that for A study $r S=0,286, \mathrm{~B} r S=0,226$, $\mathrm{C} \mathrm{rS}=0,265$, it can be concluded that there occurs only a weak, positive relationship between these values. It should be observed that this conclusion refers only to the group of Polish large and the largest cities.

\section{Conclusions}

As it has already been mentioned in the introduction, administrative reform was implemented in Poland in 1999 and one of its long-term effects was the extension of the central functions' scope by the cities which maintained their voivodship capital status [cf. 8]. This was accompanied by appropriate adjustments on the labour market, predominantly in the area of non-market services. It was connected with changing the location of public institutions, which often moved from the cities which lost their status of regional centres to the existing regional centres. Furthermore, the newly established institutions and public administration offices were, on many occasions, also located in these centres. It was reflected in the increased importance (employment number share) in Services III in the analysed cities. This observation is in line with the findings of other authors, according to which depending on the economic development of a given country or region, the share of employment changes in different sections, however, along with economic development the importance of Sector I (agriculture) decreases in favour of Sector II and III (industry and services). Further economic development is accompanied by an ongoing increase of employment in Sector III (services)[2].

It is noteworthy that the vast majority of voivodship cities were characterized by higher value of Bray-Curtis measure, and thus more dynamic transformations of the labour market structure than the average value recorded for Poland. It should be added that these cities, at the background of regions in which they function as capitals, or the country-specific average values, are characterized by higher income levels of their residents and lower unemployment rate, currently often presenting the level of natural rate of unemployment. In 11 out of 18 analysed cities the unemployment rate registered in 2016 was less than 5\% and 9\% in Białystok, as the worst in this respect [5]. 
It is interesting to note that no significant spatial pattern of cities with similar levels of Bray-Curtis measure was observed, thus a conclusion can be drawn that they are spatially dispersed. It is, however, noticeable that three of the four dual regional capitals, i.e. Gorzów, Zielona Góra, and Bydgoszcz are ranked at relatively low positions. It can be explained by the dispersion of growth factors potential into two centres. In retrospect, it is clear that the concept of administrative functions' division did not contribute to the development of the discussed cities [cf. 9]. Torun, holding the position of the ranking leader, remains the exception. It should be emphasized that also in other studies, analysing the level of investment activity in voivodship cities its position was high too [cf. 10].

There occurs only a weak positive correlation between employment structure transformations in cities and the level and rate of regional economic growth. Thus, it can be adopted that these phenomena are interrelated, however, also the entire spectrum of other, diverse factors have impact on the transformations occurring in these structures, as well as the level and pace of economic development. It would be interesting to analyse the relationship between Bray-Curtis measure and the level and changes of GDP in cities, but unfortunately these data are generated at the regional level only.

\section{References}

1. Brol, R., Maj, M., Strahl, D.: Methods of city typology. Wrocław University of Economics Press, Wrocław (1990).

2. Hełdak, M.: Planning decisions vs. cultural landscape transformations of rural areas. Wrocław University of Environmental and Life Sciences Press, Monographs CL, Wrocław (2012).

3. Kazak, J., Szewranski, S.: Indicator-based environmental assessment of spatial planning with the use of CommunityViz. In Ivan, I; Longley, P; Fritsch, D; Horak, J; Cheshire, J; Inspektor, T. (eds.) 10th International Symposium Geoinformatics for City Transformations, GIS for Safety \& Security Management 2013, vol. 51(3), pp. 163-173 Ostrava (2013).

4. Kulczyk-Dynowska, A.: Regional development in protected areas. Wrocław University of Environmental and Life Sciences Press, Wrocław (2013).

5. Local Data Bank of the Central Statistical Office, https://bdl.stat.gov.pl/BDL/start, last accessed 2017/10/22

6. Markowska, M.: Employment structure transformations in Poland in sector and regional dimension. In: Strahl, D. (ed.) Methods of regional development assessment, pp. 241-242, Wrocław University of Economics Press, Wrocław (2006).

7. Piepiora Z.: Financial Aspects of the Counteraction of Floods' Effects in the KuyavianPomeranian Voivodship (NUTS 2). In: Jedlička, P. (ed.) International Conference: Hradec Economic Days 2013 - Economic Development and Management of Regions, vol. III, pp. 319-325, Gaudeamus, Hradec Králové (2013).

8. Przybyła, K., Kachniarz, M.: The Impact of Administrative Reform on the Central Functions of Larger Polish Cities. Journal of Economic 51(3), 843-862 (2017).

9. Przybyła, K., Kulczyk-Dynowska, A., Kachniarz, M.: Quality of Life in the Regional Capitals of Poland. Journal of Economic 48(1), 181-196 (2014). 
10. Przybyła, K.: Investment activity of Polish voivodship capitals. Studies and Research Papers of the Faculty of Economic Sciences and Management of the University of Szczecin 46(2), 105-116 (2016).

11. Przybyła, K.: The level of technical infrastructure development in Polish voivodship cities. Research Papers of Wrocław University of Economics 331, 106-115 (2014).

12. Raszkowski, A., Głuszczuk, D.: Regional creativity factors. Towards new dimensions of regional development. In: Löster, T., Pavelka, T., Macáková L. (eds.) The 9th International Days of Statistics and Economics. Conference Proceedings, September 10-12, pp. 13751385. Melandrium, Prague (2015).

13. Skórska, A.: The determinants of service sector development. In: Kotlorz D. (ed.) Servitisation of Polish economy - inter-sector transformations, pp. 11-53, Research Paper of the University of Economics in Katowice, Katowice (2013).

14. Sobczyk, M.: Descriptive statistics. C.H. Beck Publishers, Warsaw (2010).

15. Świader, M., Szewranski, S., Kazak, J.: Spatial-Temporal Diversification of Poverty in Wroclaw. In Drusa, M; Yilmaz, I; Marschalko, M; Coisson, E; Segalini, A. (eds.) World Multidisciplinary Civil Engineering-Architecture-Urban Planning Symposium 2016, WMCAUS 2016, Procedia Engineering, vol. 161, pp. 1596-1600, Procedia Engineering, Prague (2016). 